Punch, S. (2005) 'The Generationing of Power: A Comparison of Child-Parent and Sibling Relations in Scotland', Sociological Studies of Children and Youth, Volume 10: 169-188.

\title{
THE GENERATIONING OF POWER: A COMPARISON OF CHILD-PARENT AND SIBLING RELATIONS
}

Although there has been much psychological research about children's sibling relations, it has been a neglected area of study in sociology (exceptions are Brannen et al., 2000; Kosonen, 1996; Mauthner, 2002). This paper, based on empirical research on siblings in Scotland, explores the nature of the generational power structure within the family from children's persectives. Childhood is a relational concept which forms part of the generational order. Alanen explains this as 'a complex set of social processes through which people become (are constructed as) 'children' while other people become (are constructed as) 'adults," (2001: 20-21). Generational processes shape the nature of child-parent relations (Mayall, 2002). Alanen states that:

one position (such as the parental position) cannot exist without the other (child) position; also what parenting is - that is, action in the position of a parent - is dependent on its relation to the action 'performed' in the child position, and a change in one part is tied to change in the other. (Alanen, 2001: 19)

In other words, child-parent relations are based on the understanding that childhood is relational with parenthood (see also Mayall, 2002). Alanen (2001) argues that the social construction of childhood and adulthood involves a process, including the agency of both children and adults, which she refers to as a set of 'practices':

It is through such practices that the two generational categories of children and adults are recurrently produced and therefore they stand in relations of connection and interaction, of interdependence (Alanen, 2001: 21)

These practices of generationing may be 'childing' practices through which people are constructed as children or 'adulting' practices through which a distinct adult position is produced. The ways in which children in the present study talked about the differences between their relationships with their parents and their siblings indicated that there are a range of generationing practices that take place within the family. They referred to particular kinds of behaviour that were acceptable to engage in with other children (in this case with their siblings) but not with their parents. Overwhelmingly the key issue which children highlighted as distinct between their relations with parents and siblings was the differential nature of power in these relationships. Whilst it is not surprising that children perceive the distribution of power to be more unequal between children and parents than between siblings, the aim of this paper is to explore the nature of this power and how it is experienced from children's point of view. In particular the paper discusses the ways in which children perceive child-parent relations compared with their sibling relationships in relation to the giving and receiving of power within the home.

I recognise that by making a broad comparison between these two kinds of relationships, there is a danger of homogenising them and overlooking diversity. As 
Dunn points out 'child-parent and child-sibling relationships are both complex and multidimensional' (1993: 90). Children's experiences of sibling relationships vary according to their age, gender and birth order (Punch, 2001), and gender also shapes adults' experiences of being a parent (Morgan, 1996). However, these intersections of birth order, gender and age are not going to be examined in this paper, but they are discussed elsewhere (Punch \& McIntosh, 2003). Since the children spoke quite distinctly about the ways in which power is exercised between siblings compared with child-parent interactions, this paper focuses on a broad comparison of these two sets of relationships whilst acknowledging the complexity and variety within them.

As the paper concentrates on an exploration of power relations within families, much of the discussion dwells on issues of conflict and control. Whilst the home can be a battleground where power struggles are played out, it is worth remembering that this is just one aspect of family relations and families can also include relationships of love, affection, caring and support (Brannen et al., 2000; Morgan, 1996). The paper begins by outlining the methods used and the definitions of power. It then discusses parental power in relation to legitimacy, household resources and children's anticipated reactions of adult discipline. The nature of sibling power is highlighted before exploring the reciprocal expectations of sibling and child-parent interactions. The paper ends by suggesting that the generationing of power relations can lead to differing degrees of backstage and frontstage performances within the home (see Goffman, 1959).

\section{METHODS}

The study began with an exploratory phase of essay-based classroom research at three local Scottish schools where 180 children (aged 7-14) wrote essays about their experiences of sibling relationships. This stage informed the design of semistructured interviews and, along with some additional snowballing, enabled access to be negotiated with a sample of 30 families with three children between the ages of 5 and 17. In these families there are not particularly large age gaps between siblings, thus it is acknowledged that in other families with wider age differences, some of the generational power issues discussed in this paper may become more relevant between siblings as well as between children and parents.

Each of the 90 siblings were interviewed individually in their homes, followed by 30 focus group interviews with all three siblings together. The group interview allowed for some sibling interaction to be observed and for group discussion of issues raised in the individual interviews. The group interviews followed the individual interviews so that any unequal power relationships between the siblings would not influence the research agenda for the individual interviews. The children were all full siblings of mixed socio-economic backgrounds, mostly living with both of their biological parents except for four single mother households. Consequently the limitations of the sample size mean that the impact of social class and different household forms cannot be fully explored. Nevertheless, the indepth and exploratory nature of the study has facilitated an examination of the kinds of processes involved in children's understandings of sibling relations.

All of the interviews included task-based methods such as spider diagrams, ranking exercises and the secret box technique (see Punch, 2002a) in an attempt to minimise 
unequal power relations between the adult researcher and child participants (see Punch, 2002b). In this paper, when using data from the interviews with children, in order to identify the quotations I use a pseudonym to protect the child's identity, followed by their age, number of family interviewed and birth order ('o' indicates oldest, ' $\mathrm{m}$ ' is middle, and ' $\mathrm{y}$ ' is youngest child). To differentiate between the individual and group interviews, I add 'Gp' at the end to indicate if the quotation was said during the group interview. In order to avoid confusion between parents and siblings, when it is unclear in the quotations I use a word in square brackets to emphasise the relationship of the person mentioned.

\section{GENERATIONAL POWER PROCESSES WITHIN THE HOME}

During the interviews I asked whether children's relationship with their parents is similar or different to their relationship with their siblings. Nearly three quarters of the children considered it to be very different. Most of the remaining quarter felt that there were some similarities but also differences and only four children said that the relationships were similar. However, although four children said that their relations with parents were 'not really different' to their sibling relationships, at other points in these interviews examples were given to indicate that the relationships were possibly different. For example, Nigel said his relationship with his siblings and parents were similar: I behave the same with both of them, but earlier he had suggested that his younger brother: thinks he can do what he wants with mum not in the house (Nigel 9, Fam 21m), thereby implying that as an older sibling, and unlike his mother, he lacks legitimate authority. Similarly, the other three children who said that their relations with parents and siblings were similar, also discussed instances of parental power which appeared to be different from sibling power: my mum comes up and gives whoever's been horrible a row, and then my brother will stop (Edward 9, Fam16m). Thus although in response to a direct question, four children felt that their relationships with parents and siblings were similar, there was also evidence that even in these interviews some differences were implicit.

Thus most of the children explicitly said that they treated their parents and siblings quite differently. Overwhelmingly the main contrast which they distinguished between their relations with parents and siblings was the differential nature of power in these relationships. Children perceived the imbalance of power to be strongly marked in inter-generational child-parent relations (see also Hartup, 1992) but lessened somewhat in the intra-generational sibling relationship (see Furman \& Buhrmester, 1985).

Power can be generally understood as 'getting what you want' (Dowding, 1996: 50), in particular 'power is the capacity to influence others' (Scott, 2001: 138). However, only a few children directly spoke using the terms 'power' or 'authority' (see also Thomas, 2000: 143):

... well mum and dad can do things, well if Tom, all Tom can do is like go upstairs, tell on us and then it's mum and dad who have more power. So it's not like Tom has the power, it's mum and dad that have the power so like you wouldn't go annoying them. (Robin 9, Fam13mGp)

Mum’s got more authority. (Rosemary 14, Fam9m) 
Most of the children expressed notions of power by talking about a person's capacity to enforce their will: Well, I think your mum and dad can force you to do things and if you're brothers and sisters you can't force them to do things (Rhoda 12, Fam27o). Their indirect discussions of power were in line with Westwood's definition of individual power as 'the will to effect changes in another actor's behaviour, context or view of the world' (2002: 14).

Albrow argues that 'power is normally structured in social relationships in a particular way, namely that one or more persons accept commands from others' (Albrow, 1990: 167; see also Smart, 1985: 73). The children in this study provided much evidence that in child-parent relations, parents tend to exercise more power over children, whereas in sibship, power is less linear and more contested. However, power is multidimensional and ubiquitous (Lukes, 1974; Westwood, 2002) and as Foucault reminds us, 'Where there is power, there is resistance' (1979: 95). Children not only have strategies for counteracting adult power over their lives, but they are also active agents with an ability to assert power over adults (Valentine, 1999) even though such power tends to be limited and constrained. When broadly comparing sibship with child-parent relations, it becomes clear that adults' generational location enables them to wield greater power (see also Buhrmester, 1992). As mentioned, whilst perhaps it is not a major revelation that parents have more power over children than siblings, it is important to consider how children understand these power differences.

There are different forms of power and it can operate at both institutional and individual levels (Westwood, 2002: 14). This study is interested in interpersonal power where individuals significantly influence each other (Scott, 2001). Weber argued that this is the form of power characterised in parent-child relations (1968: 943), rooted in everyday face-to-face contexts of interaction. Thus the family is a context in which interpersonal power is exercised both between and within generations. The family is a social institution shaped by structural generational relations, based on a social and cultural construction of both childhood and adulthood. Recent developments in the sociology of childhood have questioned traditional models of socialization where adults are assumed to be in positions of authority over children (Hockey \& James, 2003: 16). Valentine (1999) argues that children actively challenge parental authority and that nowadays families are more likely to be sites of negotiation rather than control and regulation. Nonetheless, as Brannen et al. explain, the generational distribution of power within families tends to remain unequal:

In reconceptualising children as social actors, this is not to argue that children are now seen to wield more power vis-à-vis adults, but rather to understand them as having the potential and the competences to exercise power. ... Children's lives are lived within the structural context of power in which adults regulate children's bodies and minds. In their general status as children, and in their particular statuses as sons and daughters, children's ability to act autonomously and their access to resources are constrained. (2000: 178)

Children's accounts of their family relationships indicate that families are structured by a generationing of power in which individuals draw upon resources attached to their social position: parents have more authority over me because, I'm not sure why, I think it might be because they're adults (Lucas 12, Fam17m). The rest of this paper 
explores the nature of the generational power structure within families from children's persectives.

\section{PARENTAL POWER}

All of the children in this research agreed that parents are able to exercise more power over them than siblings. Their accounts of parental power indicate that parents have legitimate authority and control over resources, both of which are interrelated mechanisms that can be used as a form of disciplinary power. This section explores these interconnected aspects of the generationing of power which are also linked to the ways in which children anticipate, and cooperate with, parental power.

\section{Legitimate Authority}

Dowding (1996) points out that legitimate authority is an obvious source of power since the force of law results in the likelihood of compliance by others. As Scott argues:

A parent exercises interpersonal power over a child, but also has certain legal rights that the child may grow up to accept and that will be recognised by others. (Scott, 2001: 30)

Parental power is linked to their functional roles as protectors and providers (Beetham, 1991: 45; Roffey et al., 1994: 7). In her research on childhoods in London, Mayall found that children perceived that:

Parents rightly had authority over their children. Many young people also provided justification for parental authority - parents knew more than children and had a duty to protect them and provide for them; so it was for them to decide how life should be lived, including how children should behave. (Mayall, 2002: 46)

In other words, there are positive and productive features of power relations (see also Hindess, 1996; Smart, 1985) as parents are expected to fulfil their responsibilities as carers. This sibling study also found that children tended to accept parental authority. When their parents asked them to do something they were much more likely to comply than if their siblings asked them. Erica explains that she is not very successful at telling her younger sister what to do:

It doesn't really work 'cos we haven't got that much of an age difference, 'cos if I boss her around then she takes it as like me having a joke and she's just going "oh shut up Erica". But if it was mum or dad who said that she would like stop doing what they were giving her a row for or something. She doesn't really take it as anything if I give her a row [a telling off], she doesn't really. (Erica 10, Fam15m)

Many of the children suggested that their obedience in response to parents or siblings was linked to a sense of what is right and wrong in the acts that are requested. On the whole parental requests were judged to be more acceptable compared with the more unreasonable demands of siblings: 
Like [sisters] tell me to go and get their socks and shoes and stuff and I just go "no you can go and get them yourself". Mum and dad tell me to clean my teeth and stuff, have breakfast. (Julianne 10, Fam7o)

Similarly Kathryn explains that her brother, Tony, and her father do not always grant her and her sister access to household resources and she interprets the legitimacy of their actions in different ways:

Like if I wanted to phone mum for any reason he wouldn't let me 'cos he's on the Internet and we've only got the one line and if I picked up the phone and waited for a while it disconnects it and he like shouts at us. ... Dad gives us a row for different things, not for wanting to phone mum or things like, 'cos Erica's always on dad's computer and she never asks, and sometimes it crashes. Like it goes dead and you can't move anything and he has to restart it and stuff 'cos that, and he just like gives her a small row. And Tony's shouting really loud and stuff. (Kathryn 9, Fam15y)

These quotations indicate that children' motivations of whether to abide by or resist commands is associated with whether or not they believe the individual has a right to make such a request. Parents are perceived to have legitimate power that is tied to their underlying parental responsibility for their children's well-being (Beetham, 1991). As Scott argues, 'Power is legitimate because it is accepted as being right, correct, justified, or valid in some way' (Scott, 2001: 20; see also Albrow, 1990: 164; Gerth \& Wright Mills, 1991: 79). Many children remarked that they are more willing to adhere to parental rules or requests rather than those given by siblings:

Interviewer: If your parents tell you to can you say no?

Simon: No we usually just do it 'cos otherwise they just end up shouting at us and there's no point. (Simon 14, Fam19oGp)

Because they think that our mum and dad are the boss and because they're oldest and they're adults, they should be in charge. But when my mum goes in the garden and my dad's at work, I've got to be in charge because I'm normally told to be but they don't like listening to me. So when I tell them to get out of the bath or something, they don't do it, they only do it when an adult says so. (Helen 10, Fam25o)

Thus, on the whole, children believe that parents have the right to tell them to do certain things, whereas siblings do not possess the same kind of legitimacy: Because he's not an adult so he doesn't have the right (Kathryn 9, Fam15yGp). Parental power is justified because of their generational and social position within the family.

\section{Resource Power}

Power is based upon resources (Dowding, 1996; Martin, 1977) and interpersonal power operates through 'the various resources on which some depend and to which others can give access,' (Scott, 2001: 28). Within the family, parents tend to control access to household resources, including income and material goods (O’Brien, 1995), as well as controlling much of children's use of time and space (Ennew, 1994). Children also depend on their parents for 'access to friends and to spaces and times outside the home' (Mayall, 2002: 48). Nearly all the children in this study confirmed 
that parents have greater control of household resources than siblings and they use these varied resources to encourage children to do as they ask:

She [mum] could say something like "oh well I'm not taking you to athletics tonight" and then, but Douglas [brother] couldn’t say that. (Rosemary 14, Fam9m)

The children are aware that parents have the capacity to manipulate the use of material resources within the home. Michael illustrates that if he disobeys his parents he would probably get a big big big ban from using my TV or the playstation (Michael 11, Fam29o). In particular, as Dowding reminds us: 'Money is an obvious source of power' (Dowding, 1996: 65) and within households parents hold most economic power:

... mum and dad pay for my martial arts so then if I usually get in trouble that's the threat that they will stop paying for all that stuff. (Simon 14, Fam19o)

Mum and dad control the money flow. (Tony 15, Fam15oGp)

Consequently parents' legitimate authority is enhanced by 'through the use of resources that can serve as punitive and remunerative sanctions', (Scott, 2001: 13; see also Galbraith, 1983: 48). The children described a range of punishments which they know that their parents may use, including being grounded, being sent to their room or to bed early, withdrawal of privileges such as use of computers or watching television, and decreased pocket money. In contrast, siblings do not have the same resources at their disposal:

Robin: Well Tom couldn't say "oh go to bed, go to your bed" like but mum and dad can.

Susan: "You can't have any tea", they can do that.

Interviewer: But can Susan never do that?

Robin: No well she could tell us off but not in the way that mum and dad could, like we probably wouldn’t listen. (Susan 12, Robin 9, Tom 5, Fam13Gp)

Tim: My brother can't exactly say 'your bed time is 7 o'clock.'

George: 'You're getting no pocket money.'

Tim: Yeah, but your mum and dad can. (George 11, Tim 9, Andy 5, Fam23Gp)

Therefore, children recognise that parents have the ability to act and enforce punishments. They believe that parents have a right to discipline them to some extent, and it is this belief and acceptance of their power which encourages children to obey their parents more than their siblings. However, as Albrow's quote reminds us, children not only adhere to parents' wishes as they respect their authority but also because they fear the consequences of not doing so:

While belief in legitimacy was a major factor in enhancing the stability of a social order, for a great deal of the time individuals were oriented towards it in terms of expediency, either from fear for the consequences if they departed from it, or from the advantages they perceived if they conformed. Equally for much of the time people adhered to an order simply because they were accustomed to do so and could see no good reason for doing anything else. (Albrow, 1990: 163) 
In addition, as Albrow suggests, responding positively to a parental request may be partly due to an acceptance of routinised everyday interactions:

Lucas: They [parents] can boss me around more.

Interviewer: How do you mean?

Lucas: Well if I have to clear a mess or tidy my room or do the washing-up then I

have to do it.

Interviewer: Can you not say no or...?

Lucas: Well I do say no most of the time but I still have to do it...

Interviewer: Is there any consequences say of not doing what they say?

Lucas: No not really but I still do it anyway. (Lucas 12, Fam17m)

Smart argues that 'Discipline is a technique of power which provides procedures for training or for coercing bodies (individual and collective),' (1985: 85). Thus parents may assert their disciplinary power for several reasons, including training and socialising children, encouraging cooperation, and maintaining order and docility within the home (see also Brannen et al., 2000). This coincides with Foucault's description of disciplinary punishment 'that operates in the process of training and correction' (1977: 180). Parental power is linked to the parenting role: 'it aims not only to constrain those over whom it is exercised, but also to enhance and make use of their capacities' (Hindess, 1996: 113).

\section{Anticipated Reactions}

For disciplinary power to be effective, the threats of withdrawal of priveleges or enforcement of spatial or temporal sanctions must be perceived as credible (see Dowding, 1996). Children can be caused to act or prevented from acting in a prohibited manner by the knowledge that parents will carry out disciplinary action:

Disciplined individuals have acquired skills, habits of action, desires, and qualities of character that allow them to act in appropriate and expected ways and to do so through the exercise of self-control. (Scott, 2001: 94)

Many children in this study claimed that the anticipated reactions of their parents was enough to encourage them to behave in certain ways:

We're a lot more sensible when our mum and dad are there and that. Just in case we get into trouble or something. (Simon 14, Fam19o)

Well, I don't argue as much with my mum and dad ... Because I know they can send me to my room and things like that. (Rhoda 12, Fam27o)

Thus children's expectation that parents will assert their authority and impose punishment can provide a motivation for certain forms of behaviour. In other words, discipline is a productive power which parents can exercise over children 'to develop their capacity for self-control’ (Hindess, 1996: 113; see also Brannen et al., 2000). In particular it can result in their cooperation rather than resistance. As Martin argues, 'compliance may result from a fear of the consequences of non-compliance' (1977: 42). 
One of the reasons why parents are able to exercise more control over children than siblings is because power is rooted in relations of dependence (Emerson, 1962: 349). Child-parent relations are based on a dyadic interdependence where the child tends to be more dependent on the adult. Parents may depend on their children for emotional attachment (Hood-Williams, 1990) and for a contribution to the domestic division of labour (Morrow, 1996) but ultimately in the UK children are very dependent on their parent's material resources (Mayall, 2002). In contrast, siblings experience a more mutual dependency on each other compared with the more unequal balance of power in child-parent relations.

This paper is concerned with the broad comparison of the nature of power in childparent relations and sibships, but obviously there is diversity within these different types of relationships. Furthermore, generational relations are cross-cut by gender, and power relations may differ according to the personal qualities of particular individuals. There is not scope in this paper to discuss these in detail, only to recognise that some variation exists in the power asserted by mothers and fathers. For example, as Mayall found in her study of London childhoods, fathers were sometimes described as the harsher authority figure (2002: 45):

They'd [parents] probably be like the bosses, dad especially, dad's more of a boss than mum. 'Cos if mum gives you a row you don't really take it as much you just think 'oh it's only mum', if dad gives you a row you're like 'OK'. (Erica 10, Fam15m)

Furthermore, there are different parenting styles across families where material rewards and punishments are used to varying degrees. Similarly, children assert their own agency choosing to resist or comply with adult power to a varied extent. They reported a range of strategies and tactics for negotiating with both parents and siblings. This concides with Mayall's findings that, within the broad framework of parental authority, children can resist and assert control over their own use of time and space (2002). Thus, generational identities are not rigidly fixed and they involve individual agency. Children are active agents in the construction of their childhood identities even though they do not necessarily experience equal capacity to assert power within the family. Nevertheless, despite recognising that children by no means passively accept parental power over their lives, broadly speaking when comparing child-parent relations with children's sibling relations, a marked difference emerges in the nature and exercise of power.

\section{SIBLING POWER}

Siblings do not possess legitimate authority, nor do they control household resources to the same degree as parents. Consequently, as children are not willing to readily accept their siblings as having power over them, 'then authority breaks down into a cruder form of power, of threats and offers' (Dowding, 1996: 64). Sometimes older siblings are left in charge of their younger siblings when their parents are temporarily absent. However, despite being granted some legitimate power on behalf of the parents, the other siblings often do not recognise their authority: if I'm in charge of them they don't actually do anything I say even if it's for their own good (Tony 15, Fam15oGp). In this research, siblings are part of the same generation and are relatively close in age, resulting in them being less likely to take seriously a command 
or an admonishment from their brother or sister. Thus parental power cannot readily be conferred from parents to older siblings because the similarity of the generational location of siblings weakens the legitimacy of even a temporary transference of power during parental absence.

Consequently different patterns of power take place between siblings. There tend to be greater power struggles and increased resistance that is more openly displayed. Power relations between siblings exist but operate in a different manner to parentchild relations. As siblings rarely have legitimate power that is recognised and accepted as right, they are more likely to use bargaining and physical power. Dowding argues that bargaining can take many forms and that, 'Each side may try to make offers or threats with whatever resources they have available' (Dowding, 1996: 66). For children these resources may include information (for example, agreeing to keep secrets from parents), a loan of material goods such as toys, computer games or CDs, and labour such as offering to undertake household chores on their behalf:

Well, normally I just ask her to do it for me and say I'll do something else for her later. (Nick 11, Fam20m)

I'd just ask them loads of times until they said yes. After that, I'd kind of make a bargain with them, like a few sweets if they did it or something.

(Michael 11, Fam29o)

Craig: Like you could say 'If you tell mum and dad that I did that, then I'll tell that you did this'

Interviewer: What sort of thing?

Craig: Say I broke a glass, say I smashed a CD that dad had bought that was old, and then I don't know, they hit somebody over the head at school and knocked them out. I could say 'if you tell mum and dad that I smashed that CD then I'll tell them that you hit someone at school'. (Craig 11, Fam26m)

Siblings engage in more complex processes of negotiation and bargaining because it is harder for them to exercise disciplinary power compared with their parents. This is perhaps why sibling power struggles are also more likely to involve physical force. The children in this research recognise that parents have greater physical strength but also that it would not be considered appropriate to initiate a fight with them (see also Foot et al., 1980: 270; Hendry, 1993: 116):

George: Well, you don't usually fall out so much with your mum and dad that much. ... Well, you don't fall out the same because if you fall out with your brother you just start fighting them.

Tim: You couldn't just punch your mum and pull her hair!

George: Because maybe if you did do it with your mum and dad, they're much stronger and I don't think they would punch you back.

Tim: You'd get in trouble (George 11, Tim 9, Andy 5, Fam23Gp)

And we hardly ever like fight with them, not like punch, punch, 'cos that would be, you never do that with your parents 'cos they'd like win. (Erica 10, Fam15m)

The children described a range of physical fighting between siblings which takes place to varying degrees of intensity. According to their accounts, physical contact during verbal arguments play a comparatively prominent role in sibling disputes 
compared with the more verbal disagreements of child-parent relations. Thus power struggles between siblings include the use of physical force to a much greater extent than between children and parents. The nature of physical fighting depends on the age and gender of siblings but, as mentioned, a detailed discussion of the intersections of gender and birth order within individual sibships remains outside the scope of this paper. The key difference between children's accounts of sibling power and parental power appears to fall in line with the two conceptions of power that Hindess identifies: power as a generalized capacity to act and power as 'involving not only a capacity but also a right to act, with both capacity and right being seen to rest on the consent of those over whom the power is exercised' (1996: 1). In other words, the power which siblings exercise is 'power as simple capacity' whereas parents operate with 'power as legitimate capacity' (see Hindess, 1996).

\section{ROUTINISED AND RECIPROCAL EXPECTATIONS}

The differential nature of power in sibships and child-parent relations shapes the particular forms of interaction which takes place between them. Goffman describes the interaction order as 'the mutual self-presentations of embodied individuals as they construct and reconstruct their identities and life plans in response to each other. It consists of a complex of everyday encounters that may become more or less routinised' (Scott, 2001: 29; see also Goffman, 1959). Therefore, within families, children and adults develop expectations of each other's behaviour during routinised social interactions. According to Scott, these encounters become 'subject to constant marginal transformations of reciprocal expectations that are largely taken for granted by the participants,' (2001: 29). The children's accounts in this research illustrate that with parents they tend to experience mutually more positive treatment whereas with siblings their actions are more likely to be provocative and reciprocally negative.

Many children remarked that they exerted more self-discipline with their parents and were more likely to behave better towards their parents than their siblings:

I behave much better with my mum and dad. ... Like I just behave much better, like I just sit down with my mum and dad, whereas with Richard and Ian I just like, they just come up and annoy, Richard comes up and annoys me and then I go and annoy Ian and then we all start in a fight. (Angus 13, Fam11m)

I'd probably be a little less mischievous. (Nick 11, Fam20m)

Well I act quite like nice and kind and things [with mother]. I wouldn't like be really annoying in front of her. (Douglas 9, Fam9y)

The different generational positions leads children to behave with more self-restraint and respect towards their parents. Partly this is a fear of the consequences if they do not, and partly it is a reflection of their acceptance of parental authority. In addition, it is because the social relationship with their parents is based on mutually orientated positive action (see also Albrow, 1990): your mum and dad behave differently to you. They don't do the same things (Graham 11, Fam4mGp). Younger siblings in particular highlighted that their parents were much more likely to treat them well: 
They're [parents] all nice to me and there's Edward [brother] sometimes he's horrible to me and mummy and daddy have never been horrible to me.

(Julian 6, Fam16y)

... like my mum and dad like I can say things to them and like they won't, it sounds a bit weird but like they won't tease me or anything. Like if I said it to my brother or sister they would probably tease me. (Jason 10, Fam22y)

It's different 'cos they're not horrible to me (parents). (Shaun 10, Fam30y)

Therefore, child-parent relations are based on a reciprocal expectation of more positive treatment which in turn leads them to get on better and argue less compared with sibships (see also Buhrmester, 1992). This is not to say that parents and children do not argue or treat each other badly at times, but comparatively speaking, it is less frequent than sibling quarrels: I don't fight with my mum and dad, well sometimes but not all the time as much. Say I said to dad "can I borrow this" and he'll say yes but the boys will say no. (Roxanna 9, Fam26y). As this quote shows, parents also are perceived as potentially more cooperative than siblings. Many children said that child-parent relations are different from sibling relations because they do not fall out with their parents to the same extent or in the same way as with sibings: It's quite different 'cos we don't always fight with them. ... 'Cos they don't steal my stuff and hog the telly, (Aleyda 12, Fam 5m).

Nicola said that if she argues with her mother: I feel bad (Nicola 14, Fam20m) but that she does not feel the same when she fights with her siblings. Several children expressed similar sentiments:

Rosemary: I don’t wind my mum up because I just wouldn’t. ... Because she’d get angry or she'd, I don't know...

Interviewer: But wouldn't Heather or Douglas if you wound them up?

Rosemary: Yeah but I wouldn't care but I care if my mum gets angry with me.

(Rosemary 14, Fam9m)

Children are more likely to regret arguing with parents than with siblings. There are several possible reasons for this: because they are more accustomed to conflict within sibling relations, there are greater negative consequences of falling out with parents and they have more respect for parents because of their generational and social position within the family. Most of the children agreed that they showed their parents greater respect than their siblings:

I look up to them [parents] (Ian 14, Fam11o)

...she [sister] just does these repeatedly annoying things. They [parents] just tell her to stop it but she'd listen to them more because she's got more respect for them.

(Samuel 16, Fam20o)

They don't respect me 'cos if I told them off and said 'you're not allowed to do that', they'd probably just, well Duncan especially, just keeps on doing it until I threaten to tell mum and then mum'll be really angry. (Michael 11, Fam29o)

You give them more the respect than your brother and sister, your brother and sister are like playmates (Erica 10, Fam15m) 
As Goffman reminds us, 'this show of respect may, of course, be motivated by a desire to impress the audience favourably, or avoid sanctions' (1959: 111). Consequently for all of the above mentioned reasons (respect, reciprocal positive treatment, parental authority and anticipated reactions), most of the children's accounts indicated that they acted in a more restrained manner with their parents, more carefully managing their presentation of self (see Goffman, 1959). Some children suggested that this could be constraining as they felt more obliged to tailor their techniques of impression management. For example, Christian explained:

Well you might be in a wee bit of a bad temper with your brothers, you show adults more respect. ... 'Cos you know that your mum and dad could punish you if they wanted to and they could do more like that. Brothers they can't. And they, you feel more free in front of your brothers and sisters than you do in front of your mum and dad. (Christian 8, Fam29m)

As Christian's quotation suggests, sibling interaction is similar to Goffman's (1959) descriptions of backstage behaviour where a performer relaxes his/her personal front and may neglect social rules of politeness and decorum. Dunn describes the ways in which siblings love and hate, play and fight, tease and mock with a 'devastating lack of inhibition' (1984: 11). There are fewer 'rules' associated with sibling interaction, and conflict is almost expected as part of 'doing' sibship (Brannen et al., 2000: 118; Buhrmester, 1992; Raffaeli, 1992). In contrast, children exert more self-control with parents, providing more of a frontstage performance where their behaviour tends to be more respectful and restrained. Thus, although sibling interactions tend to be more negative than those with parents, to a certain extent sibling encounters can be enabling, as they may allow children to more openly express their thoughts and feelings (Punch, 2002c). Furthermore, some of the children's comments indicated that when they are with their siblings away from their parents, they are allowed to do things which their mothers or fathers would not permit (see also Foot et al., 1980: 270):

Well sometimes when mum and dad aren't around we do things that we're not allowed to do in the house. ... Maybe fiddle about with things. (Michael 11, Fam29o)

... they'll [siblings] let you do stuff. (Josephine 15, Fam5o)

Interviewer: And what's that like when Jessica's in charge?

Julian: Quite fun 'cos we don't have mummy and daddy and we can do whatever we want for a wee while.

Interviewer: What sort of stuff could you do that you might not do if your mum and dad were here?

Julian: We wouldn't have to tell mummy and daddy that I'm going outside and I can go on the scooter without mummy and daddy knowing. (Julian 6, Fam16y)

On the one hand, backstage with siblings, children may be less inhibited and more able to openly express their feelings. On the other hand, because many social conventions are dropped, the relaxed atmosphere of the backstage can also lead to conflict as anger may be more easily vented (Punch, 2002c). When discussing sibling interactions, the two key words which reemerged consistently in the interviews were 
'annoying' and 'fighting'. As mentioned, child-parent relations are characterised by comparatively less arguments than sibships. The children commented that one of the main differences between parents and siblings is that parents try to intervene and sort out arguments whereas siblings tend to cause them: we don't really argue that much with mum and dad. They normally stop arguments (Nick 11, Fam20m). In other words, unlike parents, siblings are considered to be more irritating, often provoking each other into an argument on purpose:

My mum and dad aren't as annoying my three sisters. (Julianne 10, Fam7o)

I know I can be moody sometimes but I think they kind of encourage it. By just being irritating. (Heather 16, Fam9o)

Interviewer: Why do you fight less with your mum and dad?

Roxanna: Well, mum doesn't run around saying "Roxanna you're an idiot!" Or dad.

They really don't annoy me as much. (Roxanna 9, Fam26y)

However, the children did not only blame their siblings for being annoying, but they also recognised their own active role in initiating disputes. In the same way that children and parents engage in mutually more positive interactions, siblings behave in reciprocally negative manner: because they're really annoying to you so you are annoying back (Douglas 9, Fam9y).

\section{CONCLUSION}

Therefore, we have seen that the nature of child-parent and sibling relations is shaped to a large extent by their generational position and the subsequent ways in which power is exercised and resisted in these relationships. Both inter-generational and intra-generational relationships within the family involve power struggles and negotiations. Nevertheless, ultimately children are more likely to cooperate with or cede to parental power. As Valentine comments: 'parents' superior age, size and life experiences means that their power over their children is literally embodied' (1999: 150). Furthermore, children's belief in parents' legitimate authority can lead to selfdisciplined and restrained behaviour as well as avoidance of certain forms of action because of the anticipated impact of parental reactions. In contrast, siblings can not exert the same degree of disciplinary power. As a result, children do not feel the requirement to carefully manage their presentation of self during sibling interactions. Thus with siblings, on the one hand, the power they attempt to wield over each other is less effective and weaker than parental power: Well they could try to but it wouldn't normally work (Nick 11, Fam20m). Yet, on the other hand, the 'informality' of sibling interactions means that they do not have to strive to maintain a particular impression and are perhaps more free to express themselves with less fear of the consequences:

Yeah because usually mum and dad it's like we have to get on because if you want to do stuff and you want them to help you with stuff you've got to, whereas with brothers and sisters it's a bit different ... It's just a case of if you want to get on with them or not, if you want to be pals with them or if you want to just keep them out of your way, it's a bit different. (Josephine 15, Fam5o) 
Goffman explores differences in backstage and frontstage performances by drawing mainly on examples from public arenas (such as shops or restaurants) rather than from private spheres. Similiarly, authors who have used his dramaturgical framework tend to focus on formal interaction in public places (for example Chung, 1990; Gillespie, 1987). This paper has shown how different degrees of performance can be enacted within informal relationships in the private domestic sphere which is often assumed to be a backstage arena. It has suggested that interaction with siblings consists of a backstage performance whereas with parents a greater degree of frontstage performance may be required.

The child-parent relationship is informal and in comparison with more formal, public relationships such as with teachers or doctors, one could say that parents require less impression management. However, the value of comparing child-parent relations with another informal relationship, in this case sibship, is that it highlights the ways in which children can more carefully manage their presentation of self with parents than with siblings. Interaction between children and parents and between siblings is shaped by their generational positions: what is perceived as acceptable behaviour between siblings is perhaps not appropriate with parents. Within the inter-generational childparent relationship power is more likely to be exercised over children because of parents' legitimate capacity which stems from their parental role as caregiver as well as their adult status. In contrast we have seen that within the intra-generational sibling relationship power tends to be more reciprocal and exerted as a cruder form of 'simple capacity' (Hindess, 1996). The following final extract from one of the sibling group interviews sums up this generationing of power within family relationships:

Roxanna: Your mum and dad take care of you.

Craig: They're not horrible to you.

Interviewer: Why can you be horrible to brothers and sisters but not to parents?

Craig: Because they're like the same age as you. "You kissed each other last night, na na na na na na." It's stupid!

Gareth: It's okay with brothers and sisters. But with mum and dad, it's just stupid.

Craig: It's like an adult, they'll just think you're stupid.

Interviewer: But brothers and sisters won't?

Craig: You think they're stupid but they'll think you're stupid too.

(Gareth 13, Craig 11, Roxanna 9; Fam26Gp)

This quotation touches on the key themes of this paper and highlights the relational and reciprocal aspects of family relations. In order to understand the ways in which child-parent relations and sibships are shaped, we need to have an understanding of how power operates within these generationing processes. This paper has presented empirical data which illustrates the different ways in which power is played out in inter- and intra-generational relationships within the family. Power is an integral part of these generationing processes which impacts upon children's experiences of family relations.

\section{ACKNOWLEDGMENTS}

Grateful acknowledgement to the British Academy for their financial support of this study. 


\section{References}

Albrow, M. (1990). Max Weber's Construction of Social Theory. London: Macmillan.

Alanen, L. \& Mayall, B. (eds) (2001). Conceptualising Child-Adult Relations. London: RoutledgeFalmer.

Beetham, D. (1991). The Legitimation of Power. Basingstoke: Macmillan.

Brannen, J., Heptinstall, E., \& Bhopal, K. (2000). Connecting Children: Care and Family Life in Later Childhood. London: Routledge Falmer.

Buhrmester, D. (1992). The Developmental Courses of Sibling and Peer Relationships. In F. Boer \& J. Dunn (Eds), Children's Sibling Relationships: Developmental and Clinical Issues (pp.19-40). London: Lawrence Erlbaum Associates.

Chung, Y.K. (1990). At the Palace: Researching Gender and Ethnicity in a Chinese Restaurant. In L. Stanley (Ed.), Feminist Praxis (pp. 189-204). London: Routledge.

Dowding, K. (1996). Power. Buckingham: Open University Press.

Dunn, J. (1993). Young Children's Close Relationships: Beyond Attachment. London: Sage.

Dunn, J. (1984). Sisters and Brothers. London: Fontana.

Emerson, R. (1962). Power-dependence Relations. In Scott, J. (Ed.), Power, Vol 2 (pp.343-361). London: Routledge.

Ennew, J. (1994). Time for Children or Time for Adults. In Qvortrup, J., Bardy, M., Sgritta, G. \& Wintersberger, H. (Eds), Childhood Matters: Social Theory, Practice and Politics (pp.125-143). Aldershot: Avebury.

Foot, H.C., Chapman, A.J. \& Smith, J.R. (1980). Patterns of Interaction in Children's Friendships. In Foot, H.C., Chapman, A.J., \& Smith, J.R. (Eds), Friendship and Social Relations in Children (pp. 267-289). Chichester: John Wiley \& Sons.

Foucault, M. (1977). Discipline and Punish. London: Allen Lane.

Foucault, M. (1979). The History of Sexuality, Vol 1. London: Allen Lane.

Furman, W. \& Buhrmester, D. (1985). Children's Perception of The Personal Relationships in their Social Networks. Developmental Psychology, 21 (6), 10161024.

Galbraith, J. (1983). The Anatomy of Power. London: Corgi Books. 
Gerth, H. \& Wright Mills, C. (1991). From Max Weber: Essays in Sociology. London: Routledge.

Gillespie, J. (1987). The Phenomenon of the Public Wife: An Exercise in Goffman's Impression Management. In Deegan, M. \& Hill, M. (Eds), Women and Symbolic Interaction (pp. 191-210). Boston: Allen and Unwin.

Goffman, E. (1959). The Presentation of Self in Everyday Life. Harmondsworth: Penguin Books.

Hartup, W. (1992). Friendships and Their Developmental Significance. In McGurk, H. (Ed.), Childhood Social Development: Contemporary Perspectives (pp. 175-205). Hove: Lawrence Erlbaum Associates.

Hendry, L., Shucksmith J., Love J. \& Glendinning A. (1993). Young People's Leisure and Lifestyles. London: Routledge.

Hindess, B. (1996). Discourses of Power: From Hobbes to Foucault. Oxford: Blackwell.

Hockey, J. \& James, A. (2003). Social Identities across the Life Course. Basingstoke: Palgrave Macmillan.

Hood-Williams, J. (1990). Patriarchy for Children: on the Stability of Power Relations in Children's Lives. In Chisholm, L. (Ed.), Childhood, Youth and Social Change: a Comparative Perspective (pp.155-171). London: Falmer Press.

Kosonen, M. (1996). Siblings as Providers of Support and Care during Middle Childhood: Children's Perceptions. Children \& Society, 10, 267-279.

Lukes, S. (1974). Power: A Radical View. Basingstoke: Palgrave.

Martin, R. (1977). The Sociology of Power. London: Routledge and Kegan Paul.

Mauthner, M. (2002). Sistering: Power and Change in Female Relationships. Basingstoke: Palgrave Macmillan.

Mayall, B. (2002). Towards a Sociology for Childhood. Buckingham: Open University Press.

Morgan, D. (1996). Family Connections. Cambridge: Polity Press.

Morrow, V. (1996). Rethinking Childhood Dependency: Children's Contribution to the Domestic Economy. The Sociological Review, 44 (1), 58-77.

O'Brien, M. (1995). Allocation of Resources in Households: Children's Perspectives. Sociological Review 43 (3), 503-517. 
Punch, S. (2001). Household Division of Labour: Generation, Gender, Age, Birth Order and Sibling Composition. Work, Employment \& Society, 15 (4), 803-823.

Punch, S. (2002a). Interviewing Strategies with Young People: The 'Secret Box', Stimulus Material and Task-based Activities. Children \& Society, 16, 45-56.

Punch, S. (2002b). 'Research with Children: The Same or Different from Research with Adults?’ Childhood, 9 (3): 321-341.

Punch, S. (2002c). Children's Backstage and Frontstage Performances: A Comparison of Sibship and Friendship. Paper presented at the XVth International Sociological Association World Congress, Brisbane, Australia, 7-13 July 2002.

Punch, S. \& McIntosh, I. (2003). The Dynamics of Giving and Exchange between Siblings. Paper presented at Connections that Count: An International Conference on Young people, Social Capital and Empowerment, 11-14 September 2003, Glasgow: University of Strathclyde.

Raffaelli, M. (1992). Sibling Conflict in Early Adolescence. Journal of Marriage and the Family, 54, 652-63.

Roffey, S., Tarrant, T. \& Majors, K. (1994). Young Friends: Schools and Friendship. London: Cassell.

Scott, J. (2001). Power. Cambridge: Polity.

Smart, B. (1985). Michel Foucault. London: Tavistock.

Thomas, N. (2000). Children, Family and the State. Basingstoke: Macmillan.

Valentine, G. (1999). 'Oh Please, Mum. Oh Please, Dad': Negotiating Children's Spatial Boundaries. In McKie, L., Bowlby, S. \& Gregory, S. (Eds), Gender, Power and the Household (pp.137-154). Basingstoke: Macmillan.

Weber, M. (1968). Economy and Society, Volume 3. New York: Bedminster Press.

Westwood, S. (2002). Power and the Social. London: Routledge. 